\title{
Vulnerability Assessment of Cyclonic Hazards in Coastal Region of Bangladesh
}

\author{
Md. Sohel Rana ${ }^{1}$, Md. Abu Saeed Al Azad ${ }^{2}$, Md. Jahidul Islam ${ }^{3}$ \\ ${ }^{1}$ Department of Urban and Regional Planning, Pabna University of Science and Technology, Pabna, Bangladesh \\ ${ }^{2}$ Department of Planning, Development Design Consultants (DDC), Dhaka, Bangladesh \\ ${ }^{3}$ Department of Social Work, Pabna University of Science and Technology, Pabna, Bangladesh
}

Email address:

sohelrana1017051@gmail.com (Md. S. Rana), abusaeed044@gmail.com (Md. A. S. Al Azad), jahid_2412@yahoo.com (Md. J. Islam)

\section{To cite this article:}

Md. Sohel Rana, Md. Abu Saeed Al Azad, Md. Jahidul Islam. Vulnerability Assessment of Cyclonic Hazards in Coastal Region of Bangladesh. Urban and Regional Planning. Vol. 3, No. 2, 2018, pp. 34-43. doi: 10.11648/j.urp.20180302.11

Received: March 13, 2018; Accepted: March 28, 2018; Published: April 26, 2018

\begin{abstract}
The aim of this study is to identify the hazards that are associated with cyclone and to prepare hazard maps with various intensity (low, medium and high) through questionnaire survey and Participatory Rural Appraisal (PRA) method in Paikgacha Upazilla of Khulna District is a major cyclone prone area of Bangladesh. The collected data reveals that salinity, water logging, embankment erosion, tidal surge and storm surge are the major cyclonic hazards and have adverse effects on agriculture, structure, occupational pattern, consumption pattern and service facilities of that area. As a result, vulnerability assessment has done to identify the most vulnerable sector by the impacts of multi-hazard using Weighted Index method. The analysis of the data shows that structural sector $(24 \%)$ is more vulnerable compared to other sectors. Because, the housing condition is not much better condition in terms of construction material and technology. During cyclone period heavy wind speed and storm sure damage and destroy the housing roof and wall. On the other side, occupational pattern (23\%) reflects as second rank vulnerable sector in the study area. This research helps to mitigate risks by hazard mapping and plays an important role in recovery strategies against multi-hazards risks of cyclone.
\end{abstract}

Keywords: Bangladesh, Coastal Region, Cyclone, Hazard, Vulnerability

\section{Introduction}

Cyclone is a disaster that occurs almost in every year in coastal regions of Bangladesh and brings substantial damages and losses. Several disastrous cyclones have struck Bangladesh: in 1822, 1876, 1961, 1965, 1970, and 1991 [1, 2]. Earlier studies show that $80-90 \%$ of global losses and $53 \%$ of total cyclone-related deaths worldwide occur in Bangladesh [3]. About $42 \%$ of deaths related to cyclone have been recorded in Bangladesh in the last two centuries [4]. In addition to the geophysical characteristics of the Bangladesh coast, the poor socio-economic conditions of coastal inhabitants also contribute to increasing the vulnerability of inhabitants to cyclones [5]. Therefore, the increasing trend of cyclones will certainly affect the livelihoods of vulnerable populations living in low-lying coastal Bangladesh [6, 7].

Cyclones can contain damaging wind and also produce several other hazards, both directly and indirectly. Hazards are defined as "Phenomena that pose a threat to people, structures, or economic assets and which may cause a disaster. They could be either manmade or naturally occurring in our environment" [8]. Examples: Salinity, water logging, embankment erosion etc. The impact from cyclones extends over a wide area, with strong winds and heavy rains. However, the greatest damage to life and property is not from the wind, but from secondary events such as storm surges, water logging, tidal surge and salinity. When more than one hazard event impact the same area than it is called multihazard. These different hazard events may occur at the same time or may be spaced out in time. Example: Salinity, water logging, embankment erosion, tidal surge and storm surge are happens with cyclone in the same area. Multiple hazards associated with cyclone and their impact increasing the amount of losses and damage.

One of the major environmental vulnerabilities of these people has been found to extreme scarcity of drinking water, as these are full of salinity. Salinity creates a huge health problem 
in the coastal areas such as high blood pressure, dihoreah, cholera and others. Though salinity brings some convenience for shrimp cultivation but it becomes detrimental for the survivability of other fresh water fishes which affectedly become fully extinct. On the other hand, Water logging impacts on agriculture and crop production. So as a result, people's GDP goes down because Bangladesh economy is still dependent on agriculture. So decrease of GDP means decrease in agriculture, production and cash crop also. From another point of view, Embankment Erosion is an endemic and recurrent natural hazard of cyclone in Bangladesh. When rivers enter the mature stage they become sluggish and meander or braid. These oscillations cause massive embankment erosion. Every year, millions of people are affected by erosion that destroys standing crops, farmland and homestead land. It is estimated that about $5 \%$ of the total floodplain of Bangladesh is directly affected by erosion and make danger for the whole community [9]. In the coastal regions, the damage is mainly due to induced storm surges, particularly over the low elevation coastal margins. This is why; the coastal zone of Bangladesh could be termed a geographical "death trap" due to its extreme vulnerability to cyclones and storm surges [10]. The massive loss of life by cyclonic storm surge is due to the high density of population in this area, people living in poverty within poorly constructed houses, the inadequate number of cyclone shelters, and the extremely low-lying land of the coastal zone [11].

In this response, the disaster risk reduction is most fundamental issues for sustainable communities. The study focuses to identify the multiple hazards associated with cyclone and their impacts on the villagers. Hazard mapping shows the most vulnerable area by salinity, water logging, tidal surge and embankment erosion for agriculture, structure and livelihood. There is a scope for the peoples of the study area to keep free their structure, agriculture, livelihood, and livestock from those hazards after identifying the hazards zone. People also change livelihood pattern during high intensity hazards period that can significantly reduce the losses and damages. This analysis will help to identify recovery strategies against multi-hazard impact of cyclone in the study area.

\section{Study Area and Methodology}

Santa village is selected as a study area and it is located at Garaikhali Union of Paikgacha Upazilla in Khulna District. Santa village is besides the Sibsa River and located near the Sundarban. It is a major coastal area in Bangladesh and affected by cyclone in every year. Various types of hazards are associated with cyclone due to its geographic location in pre, during and after the cyclone. Salinity hazard exists all over the village and due low-lying areas water logging is a common phenomenon in this village after the cyclone. Sibsa River and their tributary hit the road embankment cause embankment erosion. Cyclonic storm surge damage and destroy most of the structure and agricultural crop.

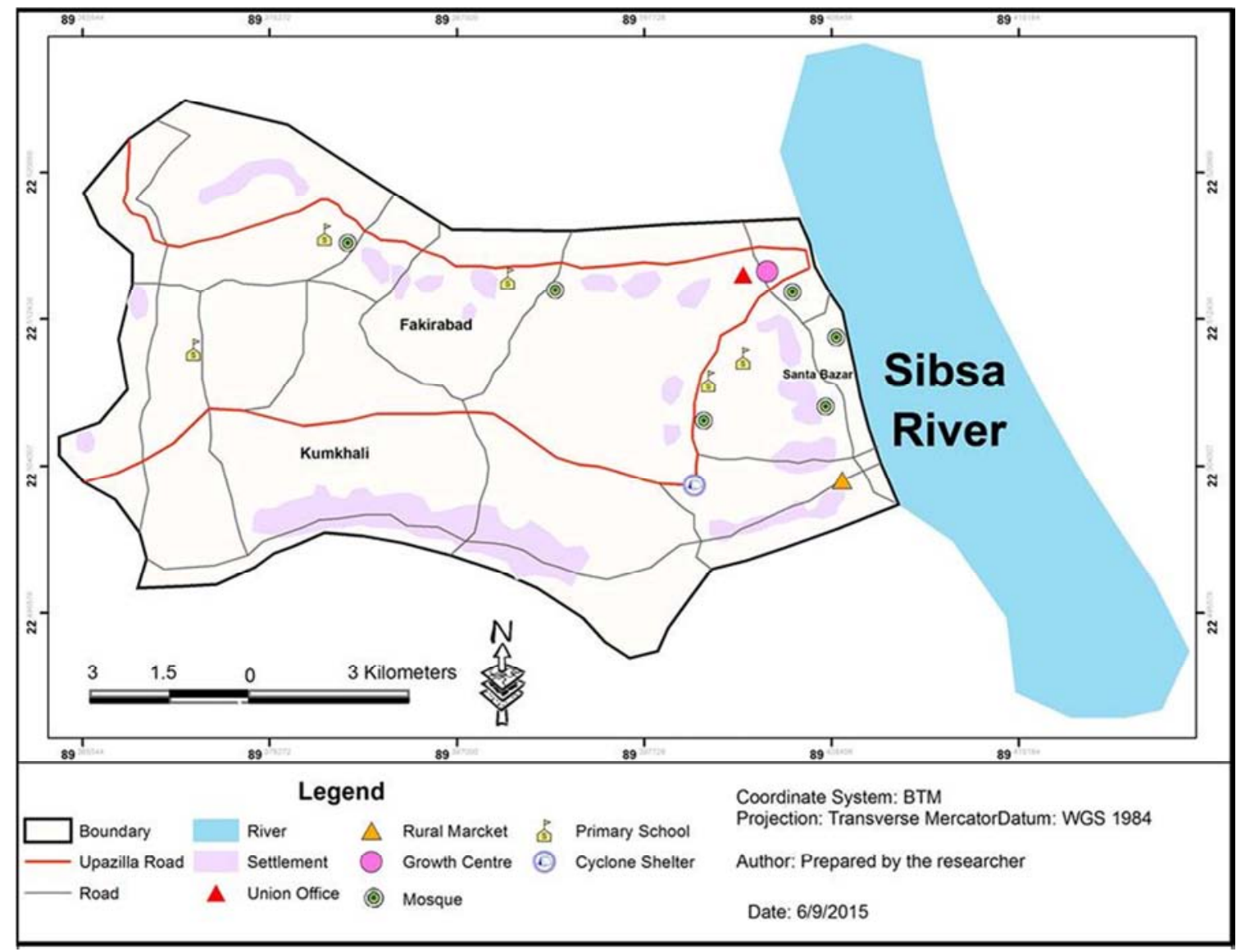

Figure 1. Study Area. 
Collection of data using per population is more time consuming and not feasible. For expected outcomes in relation with the study, two types of data have been collected in this study. Data that are collected from the field by direct observation is called primary data collection. The data are collected from different organization, website, journals etc. is called secondary data collection. The process of primary data collection concerns two steps: Questionnaire survey and Participatory Rural Appraisal (PRA) method.

A questionnaire is prepared for collecting necessary information. The questionnaire contains the following contents: Cyclone information (history, trend, frequency, duration, intensity) and hazard and impact identification (water logging, salinity, river erosion, tidal surge, structural, agricultural, fisheries, pollution, diseases etc.). By taking a $95 \%$ confidence interval, total sample size for the household questionnaire survey was 100 out of 570 households regarding feasibility of the study.

Mainly two groups of people are involved in Participatory Rural Appraisal (PRA); one is the members of Upazilla administration such as Upazilla disaster management officer and UP Chairman and the other were the mass people. The surveying based on the participation of rural people is called Participatory Rural Appraisal (PRA) survey and is conducted by two important steps.

Semi-structure Interview: At first, the map of Paikgacha Upazilla, general information like total population, village names are collected. Then, information concerned with cyclone is collected from the Upazilla disaster management office.

Focused Group Discussion (FGD): It is an easy way to gather people together to discuss a specific topic. Here, the habitants mainly 6-8 local people in selected village are gathered for FGD. They provide spatial and nominal information about cyclone. People opinion was collected about- i) History and trend of cyclone ii) Hazard Venn of cyclone iii) Hazard map (i.e. Salinity map, water logging map, vulnerability map etc.) iv) Hazard seasonal calendar v) Livelihood seasonal calendar

The secondary data are collected from department of Public Health and Engineering (DPHE), Agricultural office, Local Government and Engineering Department (LGED) and relevant information from journals. The information from PRA tools, questionnaire survey, maps and secondary sources are interpreted and analyzed with the help of different mathematical, statistical and different software tools, in accordance with the objectives. A weighted index method is used for the vulnerability assessment. The finding form various analyses was portrayed and arranged by dint of graphs and maps.

\section{Data Analysis and Findings}

\subsection{Cyclonic Hazard Profile}

\section{Hazard Venn}

Venn diagram identifies hazards of an area and find out their magnitude. Large circle size indicates higher degree of impact and overlapping of the circle indicates interactions among hazards. In the study area five types of hazards are identified. In the figure 2 various types of cyclonic hazards in Santa village are shown with impact. Here the impact of salinity is high among the hazards. Figure also shows that salinity and water logging are highly interrelated. When the water logging is very high, Salinity is also high. On the other hand, embankment erosion is caused by the tidal surge.

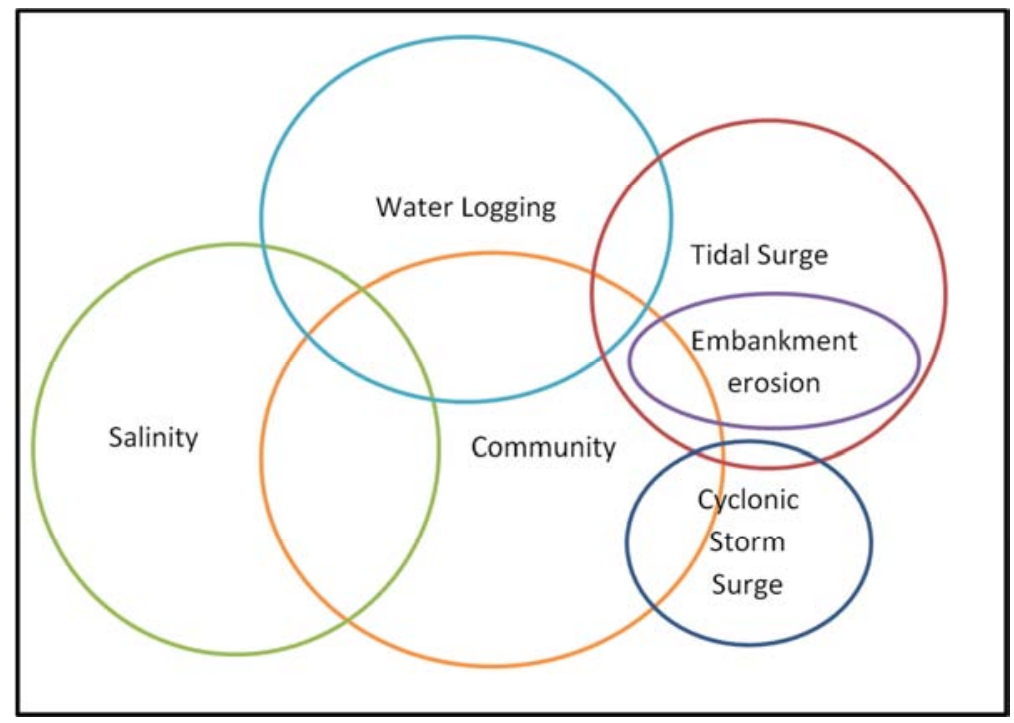

Figure 2. Hazard Venn.

Salinity Map

Salinity map is prepared based on the PRA survey. The whole village is affected by the salinity and divided into three salinity zone. Figure 3 shows that settlement and structure are located in low salinity zone. High salinity zone is used for shrimp farming. On the other side, Moderate and low salinity zone are used for crop farming. 


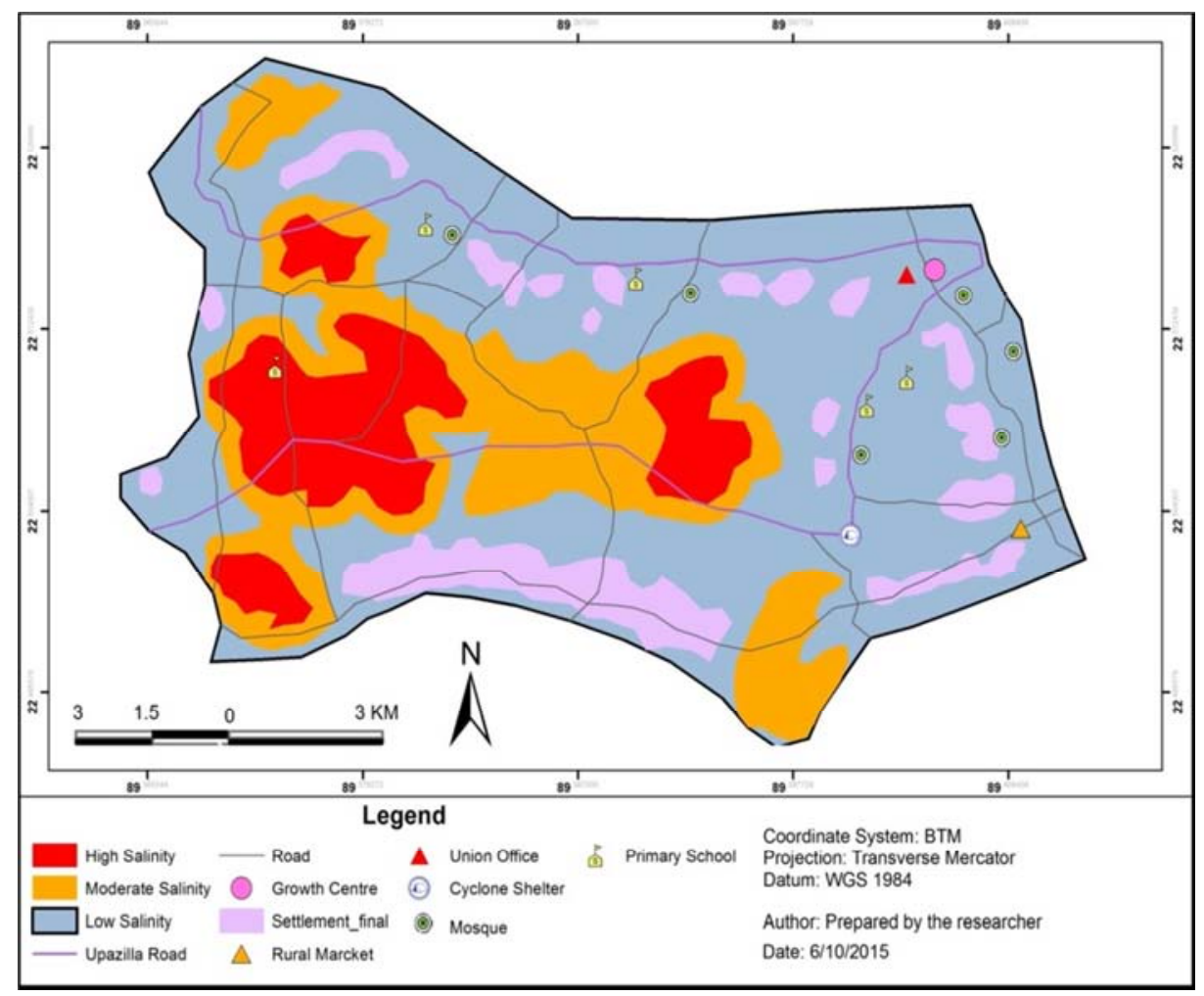

Figure 3. Salinity Map.

Water Logging Map

According to PRA survey, water logging area is divided into three zones i.e. Low, Moderate and High. Figure 4 shows that settlements are free from water logging and some road network is also affected by the water logging cause damage of the road network. Most high water logging areas are used for fisheries and shrimp farming.

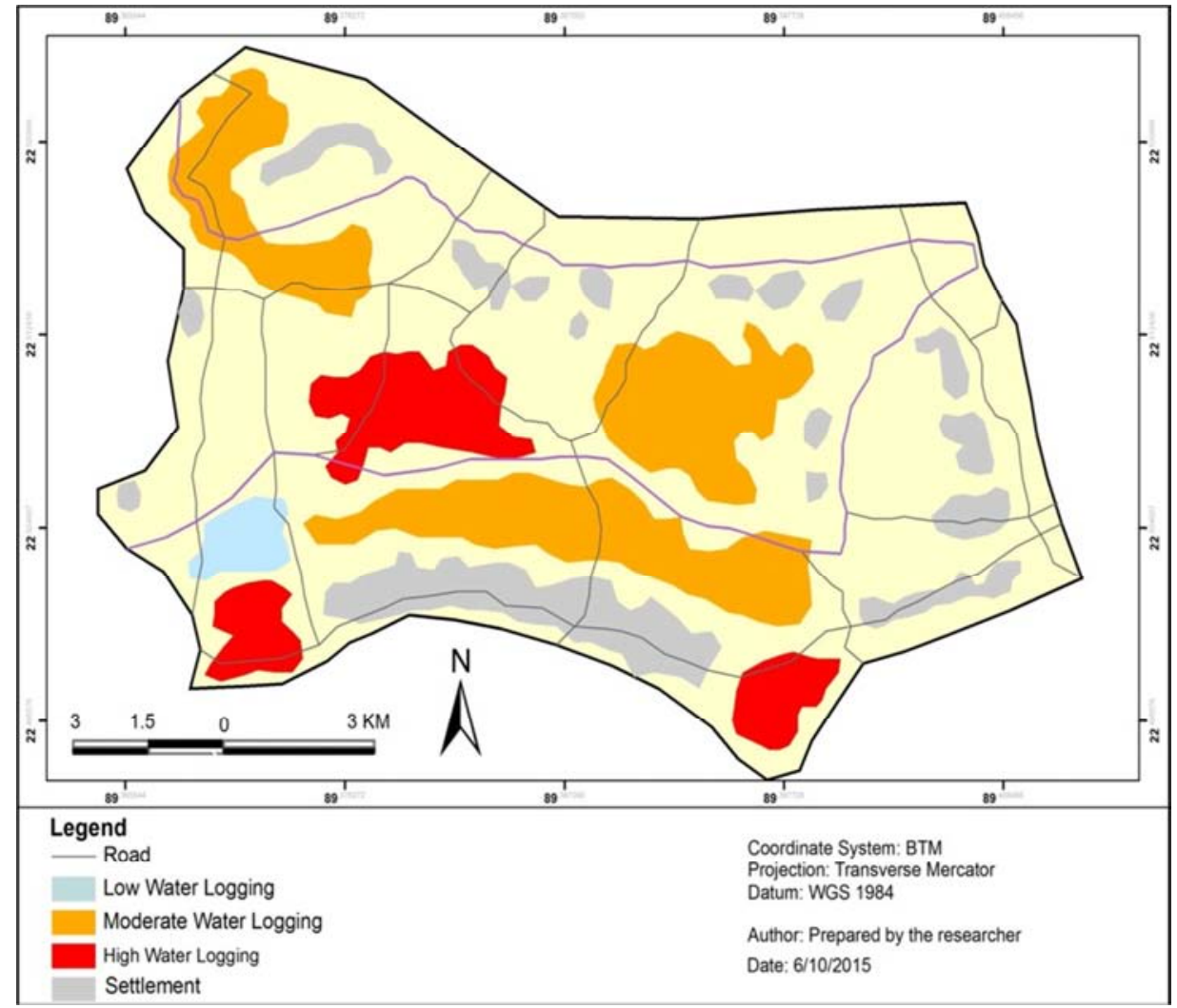

Figure 4. Water Logging Map. 


\section{Embankment Erosion Map}

Embankment erosion map is prepared based on the PRA survey. Figure 5 shows that embankments locate at the boundary line of the village and the erosion is very high near the river and their tributary. The Sibsa river is beside the village and erosion is very high is shown in the map by red mark.

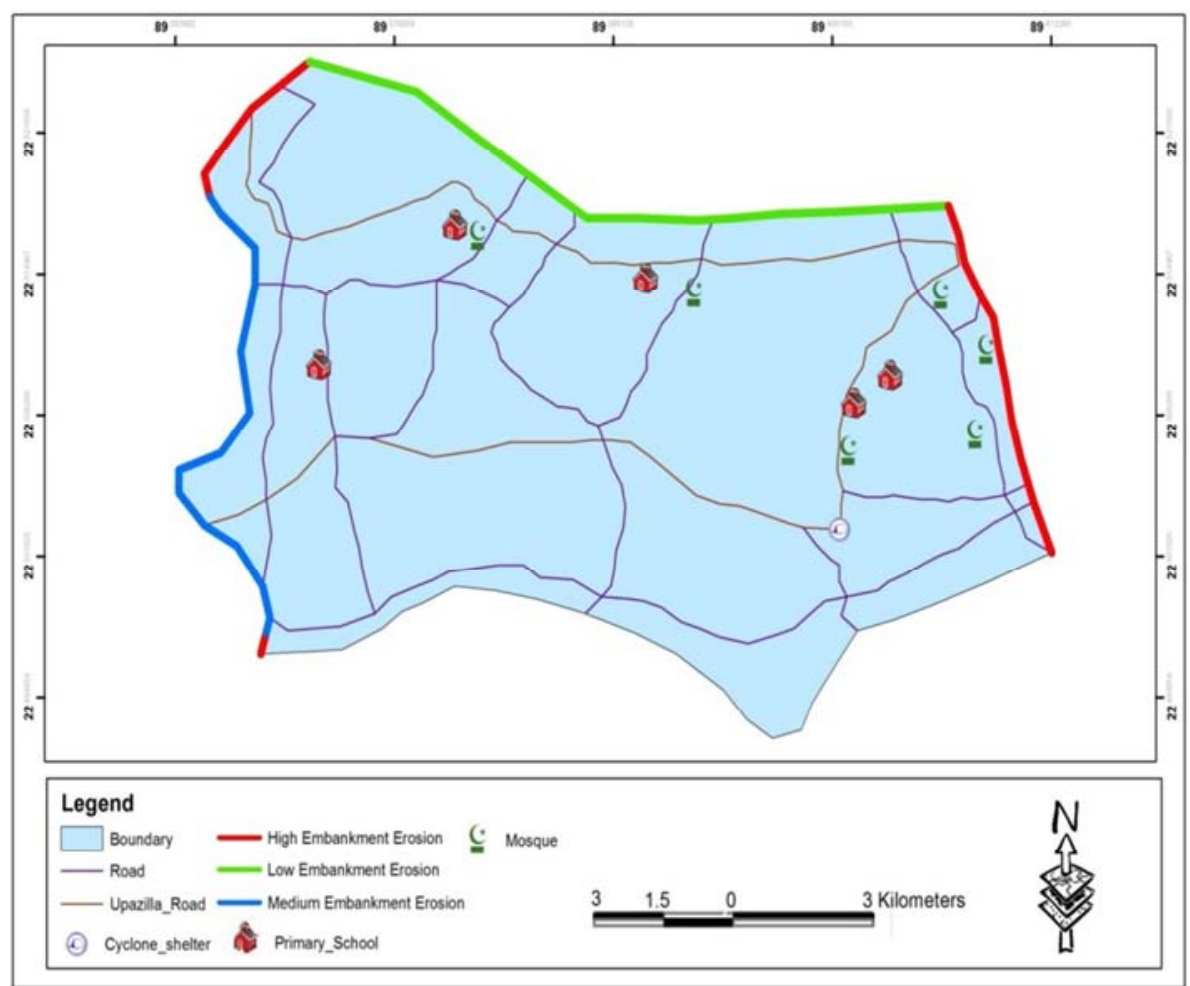

Figure 5. Embankment Erosion Map

Hazard Seasonal Calendar

Hazard seasonal calendar represents the occurrence and intensity period of cyclonic hazards of Santa village. The calendar shows that salinity intensity is very high in February to June period. Water logging, tidal surge and embankment erosion are relatively high after the cyclone. June-July is the cyclone occurrence time that's why water logging, tidal surge and embankment erosion is high in August to November period. Storm surge mainly occurred during the cyclone period.

\begin{tabular}{|l|l|l|l|l|l|l|l|l|l|l|l|l|}
\hline Hazards & Jan & Feb & Mar & Apr & May & Jun & Jul & Aug & Sep & Oct & Nov & Dec \\
\hline Salinity & & & & & & & & & & & & \\
\hline Water logging & & & & & & & & & & & \\
\hline Tidal surge & & & & & & & & & & & \\
\hline Embankment river erosion & & & & & & & & & & & \\
\hline Cyclonic storm surge & & & & & & & & & & & & \\
\hline
\end{tabular}

Figure 6. Hazard Seasonal Colander.
Legend

High

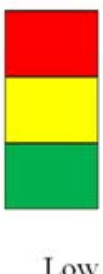

Low

Seasonal Livelihood Calendar

Seasonal livelihood calendar is a method that identifies livelihood pattern according to seasonal changes. From figure 7, rice is cultivated by the villagers from July to October due to lower level of soil salinity. For the reason of cyclonic storm surge day labors are change their activities and bound to migrate to other regions from June to July. In the time of cyclone boatman, motor cycle or van driving, cutting forest wood activities are lower level. 


\begin{tabular}{|c|c|c|c|c|c|c|c|c|c|c|c|c|}
\hline Activities & JAN & FEB & MAR & APR & MAY & JUN & JUL & AUG & SEP & OCT & NOV & DEC \\
\hline \multicolumn{13}{|c|}{ Rice farming } \\
\hline \multicolumn{13}{|c|}{ Cattle farming } \\
\hline \multirow{2}{*}{\multicolumn{13}{|c|}{ Shrimp farming }} \\
\hline & & & & & & & & & & & & \\
\hline \multicolumn{13}{|c|}{ Catching fish } \\
\hline \multirow{2}{*}{\multicolumn{13}{|c|}{ Cutting forest wood }} \\
\hline & & & & & & & & & & & & \\
\hline \multicolumn{13}{|c|}{ Renu baghda farming } \\
\hline \multicolumn{13}{|c|}{ Motor cycle/van driving } \\
\hline \multicolumn{13}{|l|}{ Boatman } \\
\hline & & & & & & & & & . & & & \\
\hline Day loor & & & & & & & & & & & & \\
\hline
\end{tabular}

Figure 7. Seasonal Livelihood Calendar.

\subsection{Vulnerability Assessment of Cyclonic Hazards}

Vulnerability Assessment of Different Sectors by Using Weighted Index Method

In weighted index method, five major criteria and their sub-criteria has been considered that is most vulnerable by the impact of cyclone. The criteria and their sub-criteria are selected after the reconnaissance survey. A weight is given for each criterion according to their importance. An impact value (1-10) is given by the professional survey and weight is given according to the field observation. The sum of the importance weighted index must be 100 and total weight obtains from field observation for each sub-criterion is also must be 100 .

The phases of the cyclone are divided into three categories. These are before, during and after the cyclone. An example of the whole procedure is given below:

Sub-criteria Score, SCS = Importance Weighting * $\sum_{i=1}^{n}\left\{\left(\mathrm{I}_{1} * \mathrm{~W}_{1}\right)+\left(\mathrm{I}_{2} * \mathrm{~W}_{2}\right)+\left(\mathrm{I}_{3} * \mathrm{~W}_{3}\right)+\ldots \ldots \ldots \ldots \ldots+\left(\mathrm{I}_{\mathrm{n}} * \mathrm{~W}_{\mathrm{n}}\right)\right\}$

Total Score of Criteria $=\sum_{i=1}^{n}\left(\mathrm{SCS}_{1}+\mathrm{SCS}_{2}+\mathrm{SCS}_{3}\right.$ $\left.+\ldots \ldots \ldots \ldots \ldots+\mathrm{SCS}_{\mathrm{n}}\right)$

Where, $\mathrm{I}=$ Impact of the sub-criteria

$\mathrm{W}=$ Weight of the sub-criteria

The table, obtained from the calculation for each major criterion, is given below:

Table 1. Weighted Index Checklists (Structure).

\begin{tabular}{|c|c|c|c|c|c|c|c|c|c|}
\hline \multirow{3}{*}{ Impact on Structure } & \multirow{3}{*}{ Importance Weighting } & \multicolumn{6}{|c|}{ Cyclone Phase } & \multirow{3}{*}{ Total } & \multirow{3}{*}{ Rank } \\
\hline & & \multicolumn{2}{|c|}{ Before } & \multicolumn{2}{|l|}{ During } & \multicolumn{2}{|l|}{ After } & & \\
\hline & & Impact & Weight & Impact & Weight & Impact & Weight & & \\
\hline House & 50 & 1 & 10 & 9 & 80 & 2 & 10 & 37500 & 1 \\
\hline School & 20 & 3 & 25 & 6 & 50 & 4 & 25 & 9500 & 3 \\
\hline Mosque & 10 & 2 & 10 & 7 & 70 & 3 & 20 & 5700 & 4 \\
\hline Shop & 20 & 4 & 20 & 8 & 70 & 2 & 10 & 13200 & 2 \\
\hline Total & 100 & & & & & & & 65900 & \\
\hline
\end{tabular}

The socio-economic condition of the people is not good and most of the people make their houses by thatch and mud. During cyclone period heavy wind speed and storm sure damage and destroy the housing roof and wall. School, mosque and shop are made by brick and tin sheet and less impacted by the cyclone and total score for structure is 65900 .

Table 2. Weighted Index Checklist (Agriculture).

\begin{tabular}{|c|c|c|c|c|c|c|c|c|c|}
\hline \multirow{3}{*}{ Impact on Agriculture } & \multirow{3}{*}{ Importance Weighting } & \multicolumn{6}{|c|}{ Cyclone Phase } & \multirow{3}{*}{ Total } & \multirow{3}{*}{ Rank } \\
\hline & & \multicolumn{2}{|l|}{ Before } & \multicolumn{2}{|l|}{ During } & \multicolumn{2}{|l|}{ After } & & \\
\hline & & Impact & Weight & Impact & Weight & Impact & Weight & & \\
\hline Crop Farming & 30 & 2 & 20 & 6 & 50 & 4 & 30 & 13800 & 2 \\
\hline Fisheries & 40 & 1 & 10 & 5 & 40 & 5 & 50 & 18400 & 1 \\
\hline Livestock & 10 & 1 & 0 & 6 & 50 & 6 & 50 & 6000 & 4 \\
\hline Shrimp & 20 & 1 & 10 & 6 & 50 & 5 & 40 & 10200 & 3 \\
\hline Total & 100 & & & & & & & 48400 & \\
\hline
\end{tabular}


Most of the lands are low-lying and people used their land for fisheries purposes. During tidal surge most of the fisheries lands are sub merged by water and greatest impacts on the farmers. People take their livestock in safe places as soon as possible after getting the cyclone warning.

Table 3. Weighted Index Checklist (Occupation).

\begin{tabular}{|c|c|c|c|c|c|c|c|c|c|}
\hline \multirow{3}{*}{ Impact on Occupation } & \multirow{3}{*}{ Importance Weighting } & \multicolumn{6}{|c|}{ Cyclone Phase } & \multirow{3}{*}{ Total } & \multirow{3}{*}{ Rank } \\
\hline & & \multicolumn{2}{|c|}{ Before } & \multicolumn{2}{|l|}{ During } & \multicolumn{2}{|l|}{ After } & & \\
\hline & & Impact & Weight & Impact & Weight & Impact & Weight & & \\
\hline Farmer & 15 & 3 & 20 & 4 & 35 & 4 & 38 & 5280 & 5 \\
\hline Fisherman & 20 & 1 & 10 & 8 & 70 & 2 & 20 & 12200 & 2 \\
\hline Business & 15 & 1 & 0 & 8 & 70 & 3 & 30 & 9750 & 4 \\
\hline Day-laborer & 30 & 1 & 5 & 9 & 80 & 2 & 15 & 22650 & 1 \\
\hline Motor bike & 15 & 1 & 0 & 9 & 80 & 2 & 20 & 11400 & 3 \\
\hline Axe man & 5 & 2 & 15 & 8 & 70 & 2 & 15 & 3100 & 6 \\
\hline Total & 100 & & & & & & & 64380 & \\
\hline
\end{tabular}

The height impact value and first rank is for day-laborer. During cyclone period day- laborer do not get any work and forced to migrate in nearby towns for their livelihood. Sometimes the whole families members are migrate whose are depends on daily income. Fisherman and motor bike driver has in the second and third rank. During cyclone period fisherman did not catch fish and motor bike driver did not drive because the road network fully or partially damaged. The impact on axe-man is very low.

Table 4. Weighted Index Checklist (Consumption Pattern).

\begin{tabular}{|c|c|c|c|c|c|c|c|c|c|}
\hline \multirow{3}{*}{$\begin{array}{l}\text { Impact on Consumption } \\
\text { Pattern }\end{array}$} & \multirow{3}{*}{ Importance Weighting } & \multicolumn{6}{|c|}{ Cyclone Phase } & \multirow{3}{*}{ Total } & \multirow{3}{*}{ Rank } \\
\hline & & \multicolumn{2}{|c|}{ Before } & \multicolumn{2}{|l|}{ During } & \multicolumn{2}{|l|}{ After } & & \\
\hline & & Impact & Weight & Impact & Weight & Impact & Weight & & \\
\hline Eating Behavior & 55 & 4 & 30 & 4 & 40 & 4 & 30 & 22000 & 1 \\
\hline Drinking Water & 45 & 1 & 10 & 6 & 60 & 3 & 30 & 20700 & 2 \\
\hline Total & 100 & & & & & & & 42700 & \\
\hline
\end{tabular}

Most of the peoples are storage food before the cyclone period. People mainly store dry food for consumption after the cyclone period. That's why storage food is the first rank. People also changing eating behavior and used pond water for drinking during the cyclone period.

Table 5. Weighted Index Checklist (Service Facility).

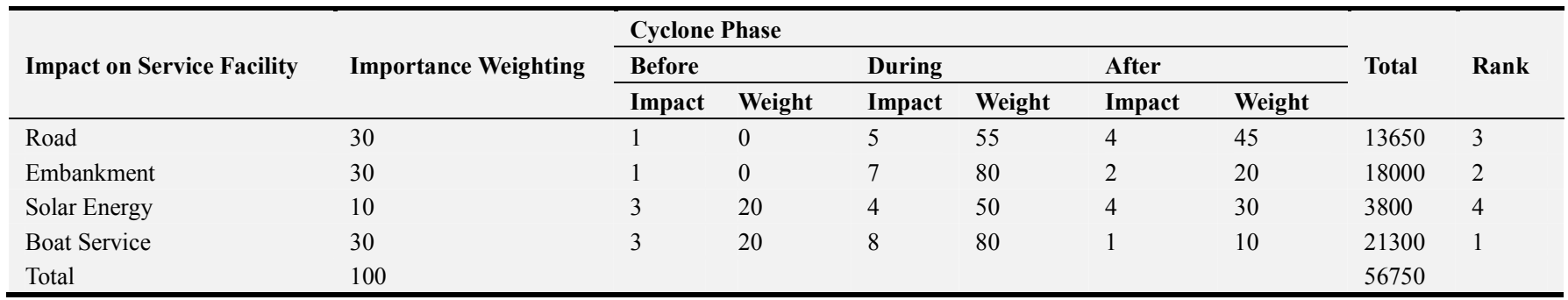

The first rank in service facilities is for boat service. During heavy storm surge and high wind speed, boat service is fully stooped. Otherwise, it could bring substantial death and loss of property. The embankment and road network are partially or fully damaged due to water logging and erosion.

According to the weighted index method, study suggests that highest percentage of value means it is most vulnerable by the impact of cyclone. Villagers build their house by local materials and structures are not strong enough to cope with the multi hazard risk of cyclone. With the $24 \%$ of the influence structural issue attains the highest impact by the cyclone around the village. About only $15 \%$ of the impact on consumption pattern due to people storage food and able to purify water during the cyclone period. On the other hand, cyclone impediments various types of occupational pattern, damage service facilities and bring agricultural losses in line with $23 \%, 21 \%$ and $17 \%$ respectively. 


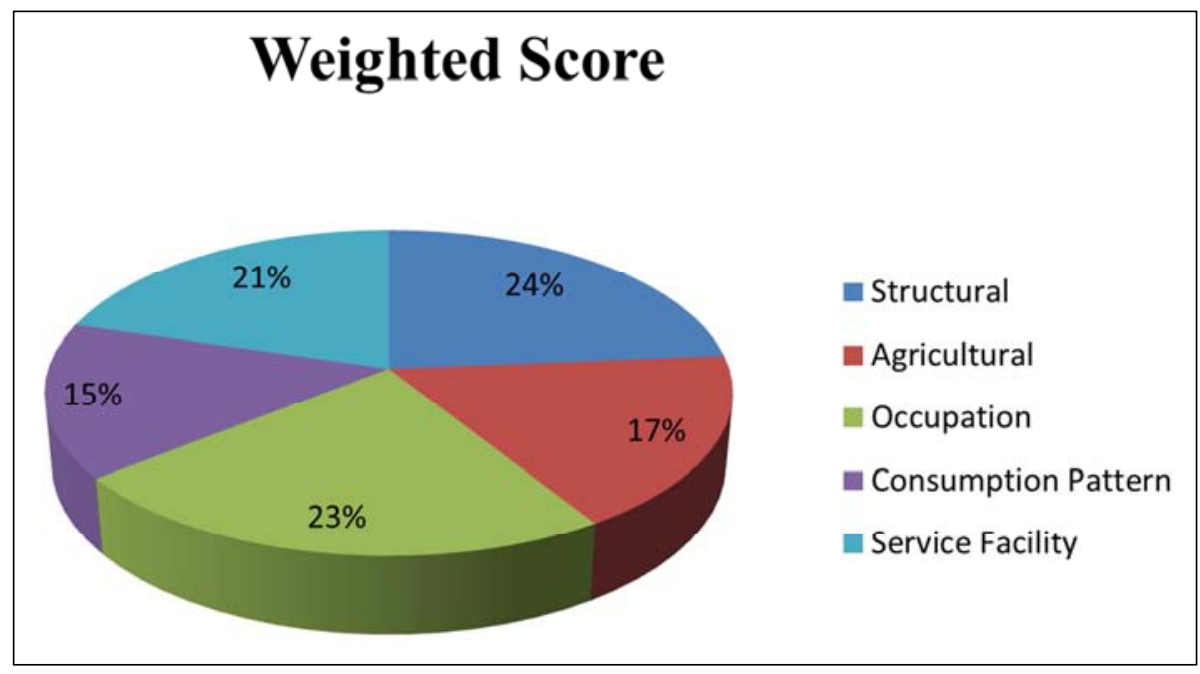

Figure 8. Weighted Score of Different Sectors.

Wind Vulnerable Structure

The map is divided into four vulnerability zone according to PRA survey. During cyclone time heavy wind speed and storm surge affects most of the structure in this village. Figure 9 shows that houses made by the thatch and mud are most vulnerable. In low vulnerable zone, most of the houses are made by the tin sheet. Mosque, primary school and shelter are made by brick and less affected by the wind. The high wind vulnerable structure is comparatively low in this village because people have a little knowledge about it.

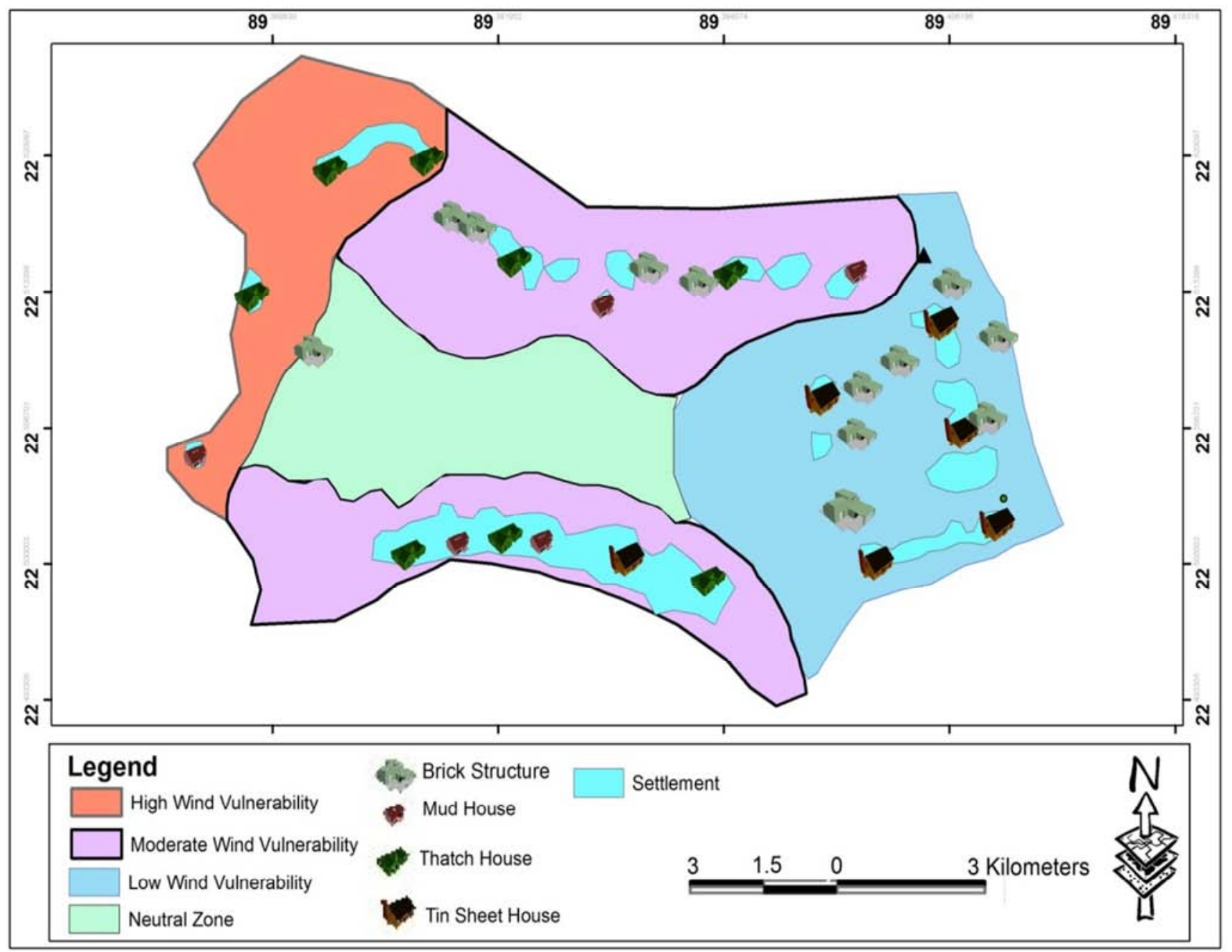

Figure 9. Wind Vulnerable Structure. 
Vulnerable Structure due to Tidal Surge and Water Logging

The map is divided into four vulnerability zone according to PRA survey. During cyclone time heavy tidal surge and water logging affects most of the cropping and fisheries land in this village. Figure 10 shows that the agricultural land and fisheries land are located in the high vulnerability zone. Settlements are less affected by the water. Sometimes, salinity damage most of the structure in this village.

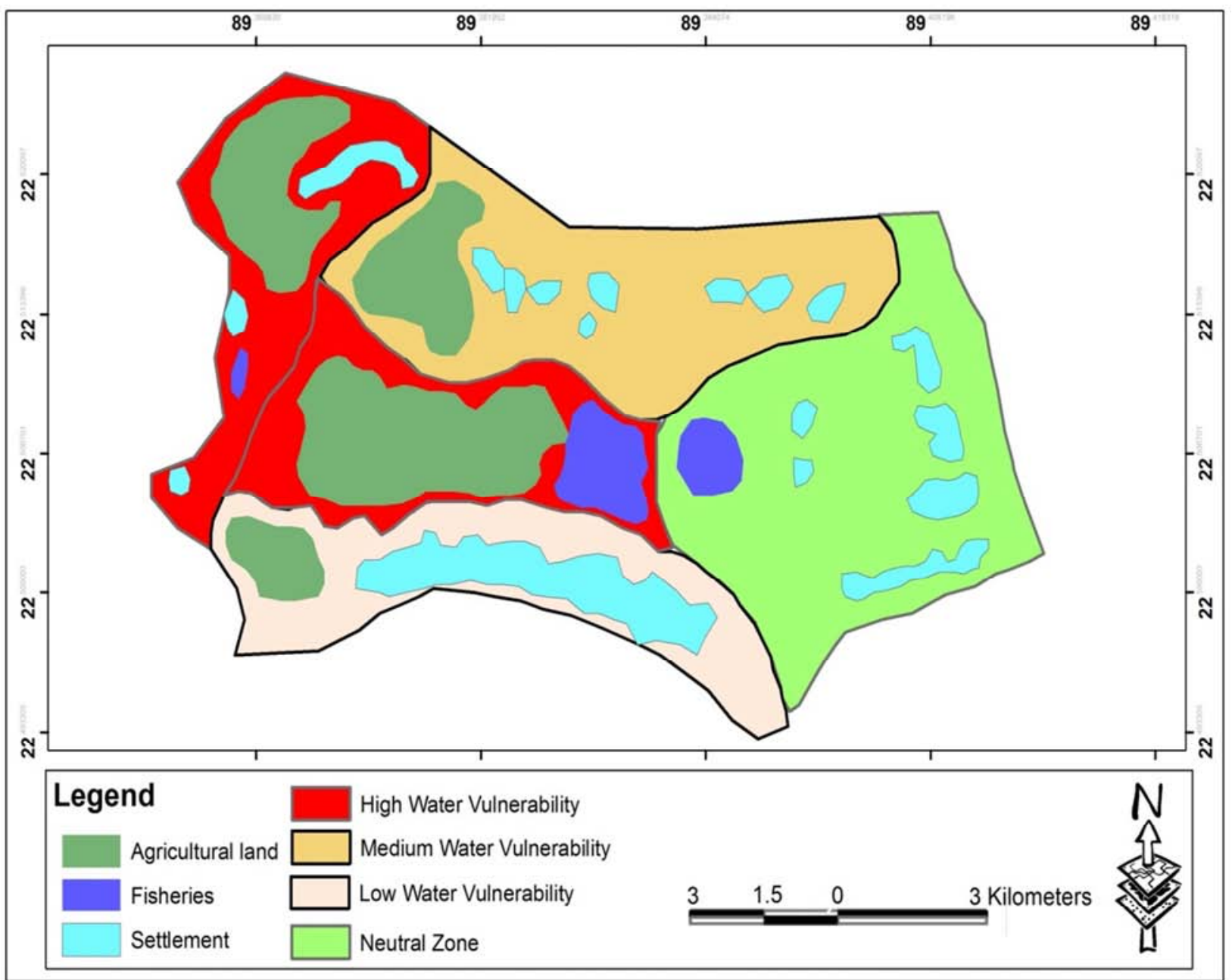

Figure 10. Vulnerable Structure due to Tidal Surge and Water Logging.

\section{Conclusion}

Hazards are the most damaging factors of cyclone and inhabitants of Santa village are familiar with cyclonic hazards and its associated risks. Multi-hazard such as salinity, water logging, tidal surge, embankment erosion and cyclonic storm surge limiting the productivity of agricultural crops, damage and destroy housing structure and also make livelihood in danger. Socio-economic status of the people is not good to resist cyclonic hazards and they change their agricultural, business and consumption pattern that increase people ability to cope with cyclonic hazards. This study provides an overview about the multi-hazard affected areas by mapping with risk variability and estimate the most vulnerable sector by using weighted index method. Thus these helps to planner and policy maker for taking further action related to plan making in cyclone prone area and able to reduce cyclonic damages.

\section{References}

[1] Wisner, B. P. B., Cannon, T., and Davis, I. (2004). "At risk: Natural hazards, people's vulnerability and disasters (2nd ed.)”. London and New York: Routledg.

[2] Dube, S. K., Chittibabu, P., Sinha, P. C., Rao, A. D., and Murty, S. T. (2004). "Numerical Modelling of Storm Surge in the Head of Bay of Bengal Using Location Specific Model". Natural Hazards, pp: 437-453.

[3] Ali, A. (1999). "Climate change impacts and adaptation assessment in Bangladesh". Climate Res., Vol. 12, pp: 109116.

[4] Nicholls, R. J. N., Mimura, N., and Topping, J. C. (1995). "Climate change in South and South-East Asia: some implications for coastal areas". Journal of Global Environmental Eng., Vol. 1, pp:137-154. 
[5] Paul, B. K. (2009a). "Why relatively fewer people died? The case of Bangladesh's cyclone sidr". Journal of Natural Hazards, Vol. 50 (2), pp: 289-304.

[6] Mian, S. M. (2005). "Generating Sustainable Employment in the Coastal Zone of Bangladesh: Present situation and future potentials". Working paper WP042, Program Development office for Integrated Coastal Zone Management, Dhaka.

[7] Islam, R. M. (2008). "Towards institutionalization of global ICZM efforts. In: Krishnamurthy RR (ed.) Integrated coastal zone management". Research Publishing Services, Singapore, pp: 23.

[8] Department of Disaster Manaement (DDM)., (na). "Disaster Management Manual". Government of West Bengal, India.
[9] Rahman, M. R. (2010). "Impact of Riverbank Erosion Hazard in the Jamuna Floodplain Areas in Bangladesh". J. Sci. Foundation, Vol. 8 (1\&2), pp: 55-65.

[10] Shamsuddoha, M., Chowdhury, R. K. (2007). "Climate change impact and disaster vulnerabilities in the coastal areas of Bangladesh". COAST Trust, Dhaka.

[11] Hossain, M. M. (2012). "Strom surges and coastal erosion in Bangladesh - State of the system, climate change impacts and 'low regret' adaptation measures". Franzius-Institute of Hydraulic, Waterways and Coastal Engineering, Faculty of Civil Engineering and Geodetic Science, Germany. 